\title{
Death due to Aortobronchial Fistula Related Massive Hemoptysis: A Case Report
}

\author{
Aortobronşial Fistüle Bağlı Masif Hemoptizi Nedeniyle Ölüm: Olgu Sunumu \\ Sait Özsoy', Hanife Alkurt Alkan ${ }^{2}$, Sultan Pehlivan ${ }^{2}$, Asude Gökmen ${ }^{2}$, Ramazan Akçan ${ }^{3}$, Metin Alkan $^{4}$
}

${ }^{1}$ Gulhane Military Medical Academy Medical School, Department of Forensic Medicine, Ankara

${ }^{2}$ Ministry of Justice, Council of Forensic Medicine, Group Chairmanship, Ankara

${ }^{3}$ Hacettepe University Department of Forensic Medicine, Ankara

${ }^{4}$ Gazi University Department of Anesthesiology and Reanimation, Ankara

*This study was presented on June 12-15, 2013 in Balkan Academy of Forensic Sciences (BAFS), Istanbul, Turkey”.

\section{Abstract}

Aortobronchial fistulas are relatively rare but usually fatal if not treated since they might cause massive hemoptysis. Here we present a case of death of a 17-year-old male due to massive hemoptysis secondary to aortobronchial fistula. The deceased was firstly admitted to an emergency department with dyspnea, tachypnea, tachycardia, resistant metabolic acidosis, confusion, and somnolence. He was diagnosed with "diabetic ketoacidosis" following examinations; however, detailed radiological and clinical investigations revealed community-acquired infection findings and medical treatment was started accordingly. He was discharged after 15 days of hospitalization; however, he died unexpectedly 12 days after discharge.

At autopsy a 4-cm aortobronchial fistula was found between the thoracic aortic wall and the left main bronchus. Histopathological examination of fistula showed diffuse and intense necro-inflammatory reaction and inflammatory response with polymorphonuclear leukocytes and necrosis. Death was attributed to massive hemoptysis and blood aspiration due to aortobronchial fistula.

A feedback system, towards healthcare centers, based on autopsy findings and exact cause and mechanisms of death will contribute improvement of diagnosis and treatment approach.

Keywords: Aortopulmonary Fistula, Respiratory Tract Fistula, Bronchial Fistula, Vascular Fistula,; Hemoptysis, Cannabinoids, Autopsy.

\section{Introduction}

Aortobronchial fistula $(\mathrm{ABF})$ is a life-threatening condition connecting thoracic aorta and tracheobronchial tree, which mainly develops secondary to atherosclerotic aneurysm or pseudoaneurysm and infection after thoracic aorta surgery or aspiration of foreign bodies. ABF incidence is not exactly known and $30 \%$ of affected patients are diagnosed at autopsy. It has been reported that $\mathrm{ABF}$ develops as a result of compression necrosis/erosion of the lung parenchyma or tracheobronchial tree next to aneurysm (1-5).

Even massive hemoptysis (bleeding at an amount $>300-500$ $\mathrm{ml} / 24$ hours or at a rate $>100 \mathrm{ml} /$ hour) is rare but the death rate

Correspoinding Author: Assoc.Prof.Dr. Sait Özsoy

Gulhane Military Medical Academy Medical School,

Department of Forensic Medicine, Ankara

E-mail: sozsoy@gata.edu.tr

\section{Özet}

Aortobronşial fistül (ABF) nadir görülen ve tedavi edilmediğinde sıklıkla masif hemoptizi nedeniyle ölüme neden olan bir durumdur. Bu makalede 17 yaşında ABF'ye bağlı gelişen masif hemoptizi nedeniyle ölen bir olgu sunulmuştur.

Olgumuz acil servise ilk olarak dispne, takipne, taşikardi, tedaviye dirençli metabolik asidoz, konfüzyon ve somnolans bulguları ile başvurmuştur. Yapılan incelemeler sonrasında "diabetik ketoasidoz" tanısı konulmuştur. Yapılan radyolojik ve klinik incelemeler sonucunda "toplumsal kaynaklı enfeksiyon” mevcut olduğu anlaşılmış ve tedavi başlanmıştır. Onbeş gün hastanede tedavi edilmiş ve taburcu edildikten 12 gün sonrasında öldüğü bildirilmiștir.

Otopside torasik aorta ile sol ana bronş arasında $4 \mathrm{~cm}$ uzunluğunda bir ABF tespit edilmiştir. Histopatolojik incelemede ABF'de polimorfonükleer lökositler ve nekroz ile birlikte diffüz ve yoğun nekro-inflamatuar reaksiyon saptanmıştır. Ölüm nedeni “ABF”ye bağlı massif hemoptizi ve kan aspirasyonu" olarak belirlenmiştir.

Otopside saptanan ölüm nedenlerinin, oluşturulacak "geri bildirim mekanizması" ile ilgili sağlık kuruluşlarına bildirilmesinin, tanı ve tedavi yaklaşımları açısından fayda sağlayacağı düşünülmüştür.

Anahtar Kelimeler: Aortopulmoner Fistuil, Solunum Sistem Fistuilü, Bronşial Fistül, Vasküler Fistül, Hemoptizi, Kannabinoid, Otopsi.

is high in $\mathrm{ABF}$ cases. Such cases are $100 \%$ fatal if left untreated according to the reported cases. But surgical treatment can achieve complete cure in $\mathrm{ABF}(2-8)$.

The disease can be diagnosed with radiological examinations, bronchoscopy, thoracic computed tomography (CT), magnetic resonance imaging (MRI), and angiography if needed. However, strong suspicion is required in order to diagnose aortic fistulas to nearby structures $(3,9,10)$.

In this report, we aimed to present a case died of massive hemoptysis due to aortobronchial fistula, with obtained postmortem examination findings.

\section{Case Report}

A 17-year-old male patient presented with dyspnea. At emergency department a Glasgow Coma Score (GCS) of 15 was observed and he was hospitalized with "diabetic 
ketoacidosis" as a result of the examinations. During treatment examinations revealed bronchitis and leukocytosis; therefore, he was diagnosed with "a community acquired infection" and treated accordingly. However, as his condition deteriorated with metabolic acidosis resistant to treatment, tachypnea, tachycardia, and somnolence, further examinations and history revealed that he took tetrahidrocannabinol (THC) (Cannabis Sativa/Cannabis Indica) and "Bonzai” (other special names: K2, Spice, etc.), a type of synthetic cannabinoid.

A thoracic computed tomography and thoracic angiotomography were performed and a hypodense area narrowing left main bronchus and neighboring esophagus was observed. There were also areas of consolidation in the left upper lobe and right lower lobe of the lung as well as an area of increased aeration in the left lung. Endoscopic examination revealed "candida esophagitis". There weren't any thoracic effusion, pathologic lymph nodes, vascular pathology, or sign of embolism.

Bronchoscopic examination revealed a dirty-yellow, endovegetative tissue, which was diagnosed as a granulation tissue obstructing bronchial lumen. The patient was hospitalized for 15 days and discharged. Twelve days after discharge he died of massive hemoptysis.

At autopsy, oral and nasal cavities as well as esophageal and tracheal lumens contained blood. The left lung was composed of three lobes and both lungs were extremely tense (Fig. 1).

A 2,5x1 cm irregular, perpendicular formation was detected in the intima of the posterior wall of thoracic aorta at $4 \mathrm{~cm}$ distal to carina. In the central part of this tissue there was a fistula defect $0.5 \mathrm{~cm}$ long that connected aortic lumen to the left main bronchus. The aortic diameter was $4 \mathrm{~cm}$ at the onset of descending aorta while it was $5.2 \mathrm{~cm}$ at the area involving the fistula (Fig. 2).

Left lung weighed 820 grams and right lung was 630 grams. There were signs of blood aspiration in sections from both lungs, in the left lung in particular (Fig. 3). Starting from carina, no macroscopic distinction could be made between bronchial wall and lumen in the left main bronchus. Stomach contained food contents mixed with 300 cc of clotted blood while duodenum and jejunum contained intestinal contents mixed with blood at their initial segments. Toxicological examination revealed "amiodarone" at a level within therapeutic range.

The tissue samples obtained at autopsy were examined by pathologists under light microscopy after staining with Hematoxylin and eosin (H\&E) stain. Histopathological examination demonstrated a region of impaired tissue integrity (fistula tract) due to diffuse necro-inflammatory reaction between thoracic aorta and the left main bronchus.

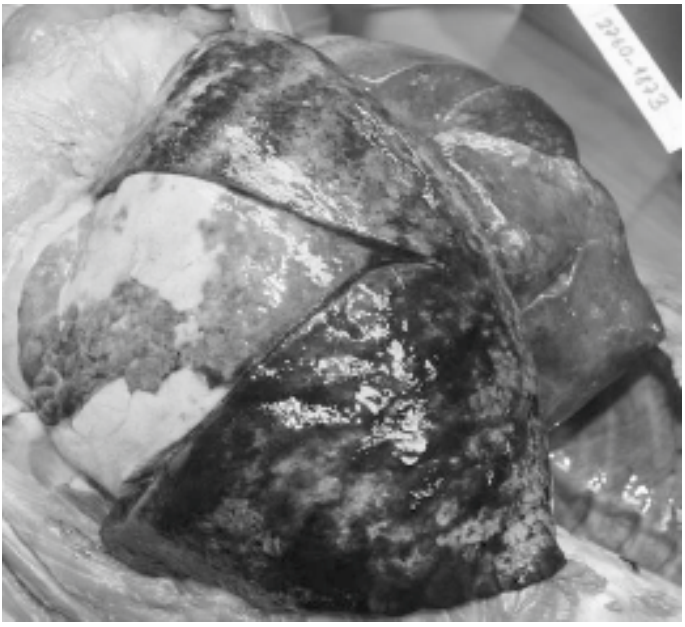

Fig 1. Extremely tense, heavy lungs (left lung: $820 \mathrm{~g}$, right lung: $630 \mathrm{~g}$.).

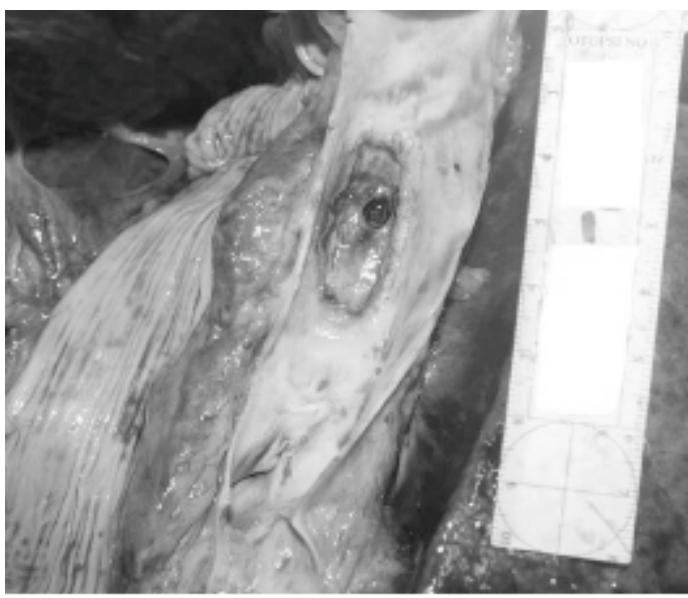

Fig 2. A fistula in the central part of aortic intimal defect (posterior wall) (fistula diameter: $0.5 \mathrm{~cm}$ )

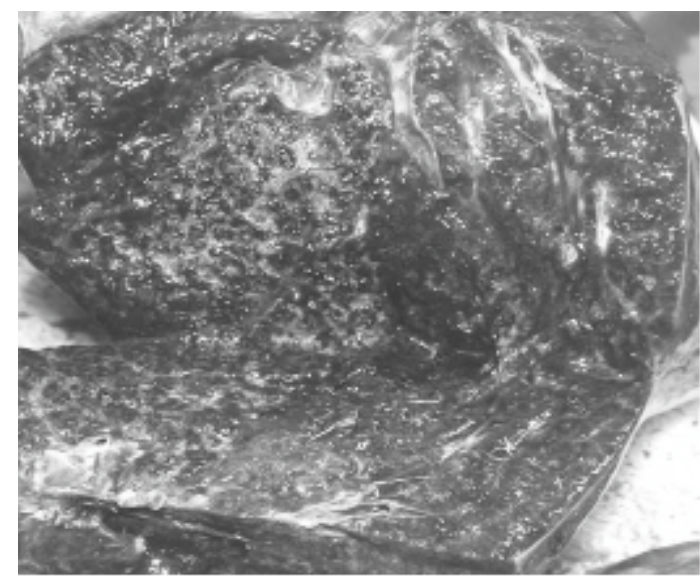

Fig 3. Blood aspiration related appearance on section of the left lung.

Intense necro-inflammatory tissue and accompanying polymorphonuclear cells were observed to degrade cartilage tissue in the fistula tract. In addition, foreign bodies, foreignbody giant cells, fungal hyphae and spores, and microorganism 
colonization were observed in necro-inflammatory tissue. Intensive blood aspiration related appearance was noticed in lung parenchyma (Fig. 4, Fig. 5, Fig. 6, Fig. 7). There were also minimal intimal thickening in coronary arteries and mononuclear inflammatory cell infiltration in pancreas parenchyma.

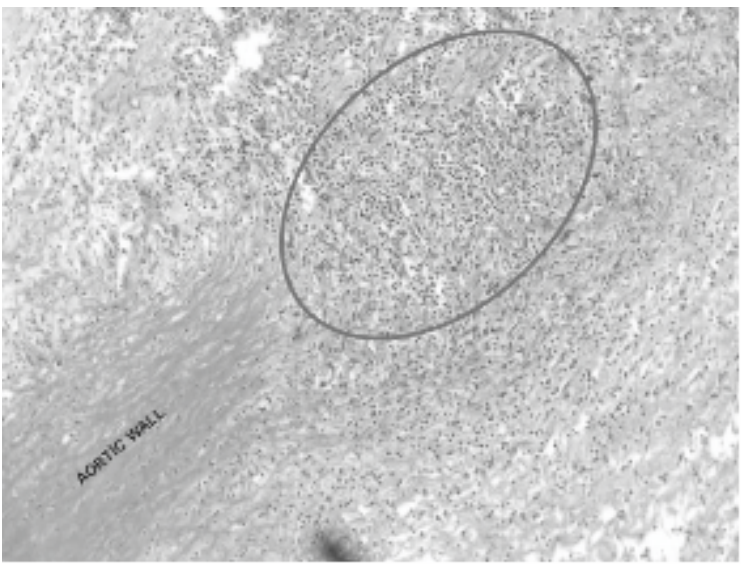

Fig 4. Acute inflammation in fistula area (HE, x10).

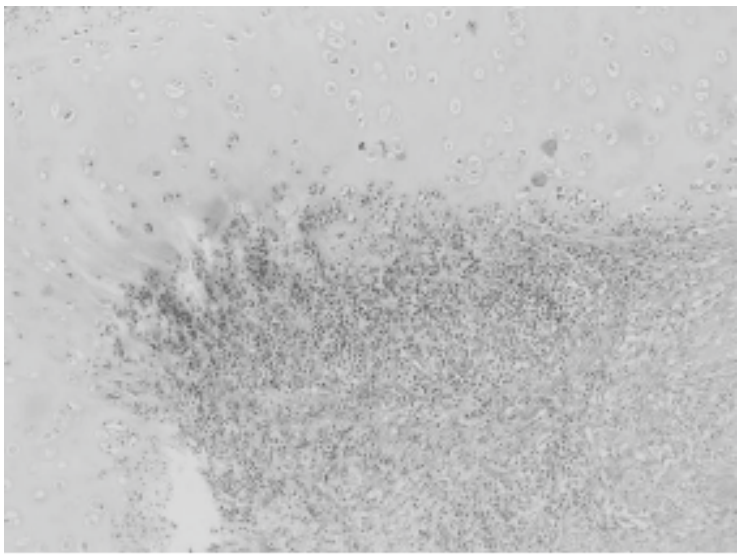

Fig 5. Mononuclear inflammatory cell infiltration in bronchial cartilage (HE X 100)

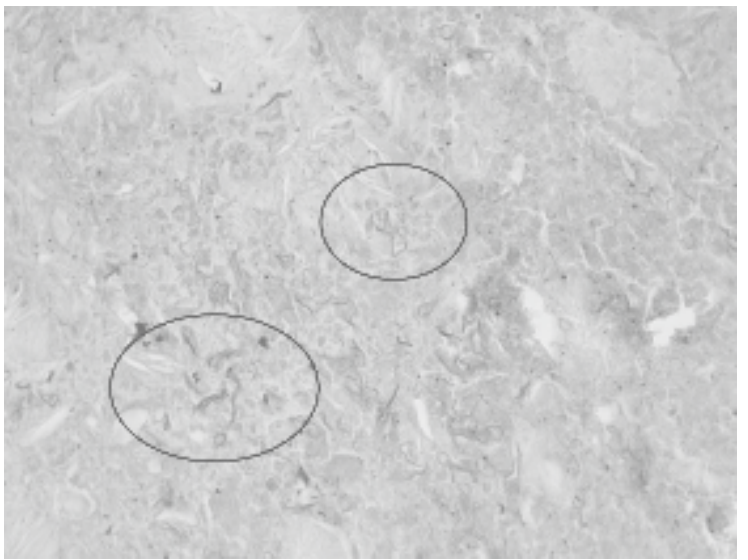

Fig 6. Foreign bodies on necro-inflammatory lung parenchyma (ellipses) (HEx400).

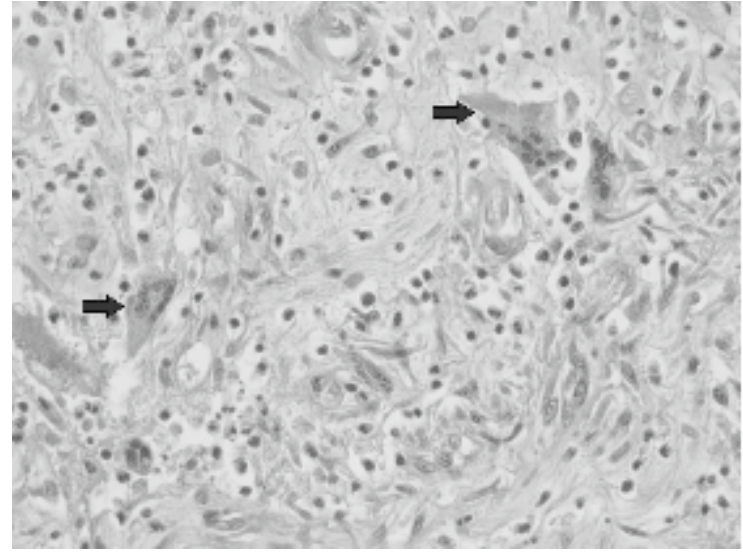

Fig 7. Inflammatory granulation tissue and foreign-body giant cells (arrows) (HE X 400).

\section{Discussion}

The main typical symptom of $\mathrm{ABF}$ is massive or intermittent hemoptysis. It has been recommended to suspect from $\mathrm{ABF}$ when hemoptysis develops especially in patients who underwent thoracic aorta surgery or have thoracic aorta aneurysm $(1,5)$. There was no history of hemoptysis (until the day he died) or a thoracic surgery before, in the presented case.

Causes and mechanisms of sudden deaths are revealed by increased number of autopsies. The most common systemic pathologies resulting in sudden death are cardiovascular and pulmonary pathologies (11). Massive hemoptysis (bleeding at an amount $>300-500 \mathrm{ml} / 24$ hours or at a rate $>100 \mathrm{ml} /$ hour) is relatively rare in $\mathrm{ABF}$, however it is responsible for a high death rate $(3,6)$. The information regarding how much blood our case lost before taken to hospital is missing. However, considering blood amount in lungs, upper airways, stomach, duodenum, and jejunum, the amount of blood loss was not less than $300 \mathrm{ml}$. Hospital records of our case states that during hospitalization consolidative areas in the left upper and right lower lobes as well as increased aeration in left lung were detected.

Drug addiction and neurological diseases are among risk factors for foreign body aspirations. Histological examinations show multinucleated giant cells, acute bronchopneumonia /bronchiolitis, and/or suppurative granulomas in such cases (12). The case had a history of abusing tetrahydrocannabinol (THC) and "Bonzai", a type of synthetic cannabinoid. Bronchoscopically, histopathological samples taken from left main bronchus showed "diffuse necro-inflammatory reaction, inflammatory reaction containing polymorphonuclear leucocytes, foreign-body giant cells, necrosis, and fresh alveolar bleeding. In the presented case, toxicological analyses were completely negative except amiodarone detected in blood in therapeutic ranges. 
There are certain articles in the literature regarding aortobronchial fistula caused by pressure necrosis from a thoracic aortic aneurysm (13). However, no primary aortic wall pathologies such as aneurysm, dissection or coarctation were detected in the presented case.

It has been reported that bronchoscopy and computed tomography could detect the source of bleeding in only $20-30 \%$ of cases with hemoptysis. On the other hand, mediastinal masses could be concealed by other mediastinal structures or secondary pulmonary changes. Interestingly, aortography has been reported to be useless in delineating fistula tract probably obstructed by a clot (3). Chest roentgenography, bronchoscopy, computed tomography (CT), CT angiography (angiogram), and magnetic resonance imaging (MRI) are often part of the evaluation of hemoptysis; however, both might fail to demonstrate the fistula and may potentially induce massive hemorrhage. In most cases, $\mathrm{ABF}$ might not be diagnosed by current diagnostic approaches $(6,10,14)$. Similarly, the presented cases could not be diagnosed despite a number of diagnostic interventions.

The presented case underwent computed tomography, angio tomography, bronchoscopy and laboratory examinations during hospital stay; however, none of these tests revealed any signs consistent with $\mathrm{ABF}$. Failure to diagnose might be contributed by placement of inflammatory granulation tissue of bronchi.

\section{Conclusion}

In $\mathrm{ABF}$ related deaths there might not be sufficient antemortem medical history or deceased might die before diagnosis. Considering that the one third of $\mathrm{ABF}$ cases diagnosed during autopsy, the causes of hemorrhages need to be investigated in detail by forensic medicine specialists. A feedback system, towards healthcare centers, based on autopsy findings and exact cause and mechanisms of death will contribute improvement of diagnosis and treatment approach. Additionally, inclusion forensic medicine approach to multidisciplinary case discussions will strengthen the clinical collaboration between disciplines.

\section{Ethical approval}

Obtained from scientific committee of TR Ministry of Justice Council of Forensic Medicine Istanbul, Turkey.

\section{References}

1. Kokotsakis J, Misthos P, Athanasiou T, Romana C, Skouteli E, Lioulias A, et al. Endovascular stenting for primary aortobronchial fistula in association with massive hemoptysis. Tex Heart Inst J 2007;34:369-72.

2. Riesenman PJ, Brooks JD, Farber MA, Hill C. Thoracic endovascular aortic repair of aortobronchial fistulas. J Vasc Surg 2009;50:992-8.

3. MacIntosh EL, Parrott JC, Unruh HW. Fistulas between the aorta and tracheobronchial tree. Ann Thorac Surg 1991;51:515-519.

4. Schils F, Deprez AF, Creemers E, Jacquemin D, Limet R. Rupture of a thoracic aneurysm in the left bronchus. Acta Chir Belg 2000 Mar-Apr;100(2):74-6.

5. Bailey CJ, Force S, Milner R, Kasirajan K, Veeraswamy RK. Thoracic endovascular repair as a safe management strategy for aortobronchial fistulas. J Vasc Surg 2011;53:1202-9.

6. Riesenman PJ, Brooks JD, Farber MA. Thoracic endovascular aortic repair of aortobronchial fistulas. J Vasc Surg 2009;50:992-8.

7. Posacioglu H, Apaydin AZ. Pseudoaneurysm and aortobronchial fistula after aortic coarctation repair by patch aortoplasty. Tex Heart Inst J 2004;31(3):319-321.

8. Andersen PE. Imaging and interventional radiological treatment of hemoptysis. Acta Radiol. 2006 Oct;47 (8):780-92.

9. Pehlivan S, Kara D, Turkkan D, Akcan R, Gökmen A, Akduman B, et al. Fatal aorto-esophageal fistula in child: a case report. Journal of Forensic and Legal Medicine 2014; 22: 112-114.

10. Böckler D, Schumacher H, Schwarzbach M, Ockert S, Rotert H, Allenberg JR. Endoluminal stent-graft repair of aortobronchial fistulas: bridging or definitive long-term solution? J Endovasc Ther. 2004;11:41-48.

11. Sam B, Akkaya H, Sahin F, Akcay A, Ozdemirel R, Ilingi U. Death due to bleeding of primary aortoesophageal fistula secondary to thoracic aneurysm: a case report. J For Med 2014;28(1):91-6.

12. Mukhopadhyay S, Katzenstein ALA. Pulmonary disease due to aspiration of food and other particulate matter: a clinicopathologic study of 59 cases diagnosed on biopsy or resection specimens. American Journal of Surgical Pathology 2007;31(5):752-759.

13. Li M, Langlois N, Byard RW. Fatal aortobronchial fistula. Journal of Forensic and Legal Medicine 2013;20:395-398.

14. Piciche' M, De Paulis R, Fabbri A, Chiariello L. Postoperative aortic fistulas into the airways: etiology, pathogenesis, presentation, diagnosis, and management. Ann Thorac Surg 2003;75:1998-2006. 